\title{
Impairment of Nitric Oxide Pathway by Intravascular Hemolysis Plays a Major Role in Mice Esophageal Hypercontractility: Reversion by Soluble Guanylyl Cyclase Stimulator
}

\author{
D Fabio Henrique Silva, Kleber Yotsumoto Fertrin, Eduardo Costa Alexandre, \\ Fabiano Beraldi Calmasini, Carla Fernanda Franco-Penteado, and Fernando Ferreira Costa \\ Hematology and Hemotherapy Center (F.H.S., K.Y.F., C.F.F.-P., F.F.C.) and Department of Pharmacology, Faculty of Medical \\ Sciences (E.C.A., F.B.C.), University of Campinas, Campinas, São Paulo, Brazil; and Division of Hematology, University of \\ Washington, Seattle, Washington (K.Y.F.)
}

Received April 1, 2018; accepted July 30, 2018

\begin{abstract}
Paroxysmal nocturnal hemoglobinuria (PNH) patients display exaggerated intravascular hemolysis and esophageal disorders. Since excess hemoglobin in the plasma causes reduced nitric oxide (NO) bioavailability and oxidative stress, we hypothesized that esophageal contraction may be impaired by intravascular hemolysis. This study aimed to analyze the alterations of the esophagus contractile mechanisms in a murine model of exaggerated intravascular hemolysis induced by phenylhydrazine (PHZ). For comparative purposes, sickle cell disease (SCD) mice were also studied, a less severe intravascular hemolysis model. Esophagus rings were dissected free and placed in organ baths. Plasma hemoglobin was higher in $\mathrm{PHZ}$ compared with SCD mice, as expected. The contractile responses produced by carbachol (CCh), $\mathrm{KCl}$, and electrical-field stimulation (EFS) were superior in $\mathrm{PHZ}$ esophagi compared with control but remained unchanged in SCD mice. Preincubation with the NO-independent soluble guanylate
\end{abstract}

cyclase stimulator 3-(4-amino-5-cyclopropylpyrimidin-2-yl)1-(2-fluorobenzyl)-1H-pyrazolo[3,4-b]pyridine (BAY 41-2272; $1 \mu \mathrm{M})$ completely reversed the increased contractile responses to $\mathrm{CCh}, \mathrm{KCl}$, and $\mathrm{EFS}$ in $\mathrm{PHZ}$ mice, but responses remained unchanged with prior treatment with NO donor sodium nitroprusside $(300 \mu \mathrm{M})$. Protein expression of 3-nitrotyrosine and 4-hydroxynonenal increased in esophagi from $\mathrm{PHZ}$ mice, suggesting a state of oxidative stress. In endothelial nitric oxide synthase gene-deficient mice, the contractile responses elicited by $\mathrm{KCl}$ and $\mathrm{CCh}$ were increased in the esophagus but remained unchanged with the intravascular hemolysis induced by PHZ. In conclusion, our results show that esophagus hypercontractile state occurs in association with lower NO bioavailability due to exaggerated hemolysis intravascular and oxidative stress. Moreover, our study supports the hypothesis that esophageal disorders in $\mathrm{PNH}$ patients are secondary to intravascular hemolysis affecting the NO-cGMP pathway.

\section{Introduction}

The nitric oxide (NO)-cGMP signaling pathway is well known to regulate smooth muscle relaxation and contraction (Förstermann and Sessa, 2012). Upon stimulation by NO, the smooth muscle soluble guanylate cyclase (sGC) enzyme catalyzes the production of cGMP following activation of cGMP-dependent protein kinase, which leads to smooth muscle relaxation from different kinds of tissues (Francis et al., 2010; Förstermann and Sessa, 2012). Alterations of the NO signaling pathway in the vascular or nonvascular smooth muscle have been associated with several disorders, such as cardiovascular disease and gastrointestinal disease (Mearin et al., 1993; Förstermann and Sessa, 2012).

F.H.S. and F.F.C. thank São Paulo Research Foundation (FAPESP) for financial support [Grants 2014/00984-3, 2017/08122-9, and 2018/06243-6].

https://doi.org/10.1124/jpet.118.249581.
The gastrointestinal tract consists of a muscular tube that extends from the mouth to the anus. The esophagus is part of the gastrointestinal tract, and its function is transporting swallowed food into the stomach and preventing gastroesophageal reflux (Yazaki and Sifrim, 2012). Esophagus smooth muscle receives a rich cholinergic excitatory innervation, resulting in the discharge of acetylcholine that acts on the muscarinic receptor of smooth muscle and promoting esophageal smooth muscle contractions (Goyal and Chaudhury, 2008; Braverman et al., 2009). NO produced by nitrergic nerves is considered the principal inhibitory neurotransmitter that promotes smooth muscle relaxation of the esophagus (Shah et al., 2004; Goyal and Chaudhury, 2008). A previous study showed mRNA expression of endothelial nitric oxide synthase in human esophageal mucosa (Inamori et al., 2006). Esophagus contraction induced by cholinergic nerve stimulation is increased by NO production inhibition, as well as esophageal peristalsis (Yamato et al., 1992; Lecea et al., 2011).

ABBREVIATIONS: BAY 41-2272, 3-(4-amino-5-cyclopropylpyrimidin-2-yl)-1-(2-fluorobenzyl)-1H-pyrazolo[3,4-b]pyridine; CCh, carbachol; EFS, electrical-field stimulation; eNOS ${ }^{-1-}$, endothelial nitric oxide synthase gene-deficient; 4-HNE, 4-hydroxynonenal; NO, nitric oxide; 3-NT, 3-nitrotyrosine; $\mathrm{O}_{2}^{-}$, superoxide anion; pEC50, potency; $\mathrm{PHZ}$, phenylhydrazine; $\mathrm{PNH}$, paroxysmal nocturnal hemoglobinuria; SCD, sickle cell disease; sGC, soluble guanylate cyclase; SNP, sodium nitroprusside. 
A previous study reported that guanylyl cyclase gene-deficient mice display higher esophagus contractions compared with wild mice (Groneberg et al., 2015).

Paroxysmal nocturnal hemoglobinuria $(\mathrm{PNH})$ is a rare acquired clonal hematopoietic stem cell disease in which uncontrolled complement activation leads to intravascular hemolysis (Oni et al., 1970; Hill et al., 2017). PNH patients display dysphagia/odynophagia, and these alterations seem to be due to esophageal spasm, but the mechanisms underlying esophageal dysfunction are largely unknown (Moyo et al., 2004; Parker et al., 2005). Sickle cell disease (SCD) is also a blood disorder that manifests with hemolytic anemia, but to the best of our knowledge, SCD patients do not display esophageal disease. In PNH and SCD, intravascular hemolysis is a common hallmark, but this clinical evidence is less severe in SCD than in PNH (Reiter et al., 2002; Hill et al., 2010). In intravascular hemolysis, erythrocyte lysis in the circulation leads to release of free hemoglobin and other erythrocyte components into the plasma, such as asymmetric dimethylarginine, arginase-1, and lactate dehydrogenase (Reiter et al., 2002; Hill et al., 2010; Kato et al., 2017). It is well established that NO scavenging by an excess of plasma hemoglobin contributes to several clinical complications of intravascular hemolysis (Hill et al., 2010; Kato et al., 2017).

The contribution of oxidative stress to the deleterious effects of intravascular hemolysis has been previously shown (Fibach and Dana, 2015). A result of oxidative stress is the inactivation of $\mathrm{NO}$ biologic activity by superoxide anion $\left(\mathrm{O}_{2}^{-}\right)$excess (Pacher et al., 2007). In this study, since cell-free hemoglobin excess and oxidative stress reduce the amount of bioavailable NO, we hypothesized that exaggerated intravascular hemolysis could damage normal smooth muscle function in the esophagus. We aimed to evaluate the esophagus smooth muscle contractile function in a murine model that displays intravascular hemolysis induced by phenylhydrazine (PHZ). PHZ-treated mice have been used to elucidate the intricate pathophysiology of hemolysis (Lim et al., 1998; Zhang et al., 2013; Dutra et al., 2014). Hemolysis may be either intravascular or extravascular, but there is some controversy over the amount of intravascular hemolysis in SCD (Crosby, 1955; Bunn et al., 2010). There are few studies on this subject, but the amount of intravascular hemolysis seems to be less than $30 \%$ of total hemolysis (Crosby, 1955; Bunn et al., 2010). As a comparison, SCD transgenic mice were also studied with the same procedure. We focused on the effects of intravascular hemolysis on contractile mechanisms and the NO signaling pathway in esophagus smooth muscle.

\section{Materials and Methods}

Animals and Treatment. Animal procedures and experimental protocols were performed in accordance with the Ethical Principles in Animal Research adopted by the Brazilian College for Animal Experimentation and followed the Guide for the Care and Use of Laboratory Animals (Ministério da ciência, tecnologia, inovações e comunicações; 2016).

All mice strains were originally purchased from Jackson Laboratories (Bar Harbor, ME). Characterization and breeding were performed at the Multidisciplinary Center for the Investigation of Biologic Science in Laboratory Animals of the University of Campinas. We used C57BL/6 male mice (control), endothelial nitric oxide synthase gene-deficient $\left(\mathrm{eNOS}^{-/-}\right)$mice, and male Berkeley transgenic SCD mice, aged 3-4 months, housed three per cage on a 12-hour light-dark cycle.
We injected PHZ at $50 \mathrm{mg} / \mathrm{kg}$ into $\mathrm{C} 57 \mathrm{BL} / 6$ and $\mathrm{eNOS}^{-1-}$ mice intraperitoneally to induce intravascular hemolysis. Mice were reinjected with $50 \mathrm{mg} / \mathrm{kg} 8$ hours later (Lim et al., 1998) and were killed with inhaled isoflurane 4 days after the end of PHZ treatment.

C57BL/6 and PHZ mice received deferoxamine $(150 \mathrm{mg} / \mathrm{kg}$ per day via i.p. injection, from second to fourth day), deferiprone ( $50 \mathrm{mg} / \mathrm{kg}$ per day, given as daily gavage from second to fourth day), or vehicles (saline and water, respectively).

Hematologic Parameters. Whole blood was obtained by intracardiac puncture from ketamine/xylazine-anesthetized mice and anticoagulated with ethylenediamine tetraacetic acid for blood count determination within 30-60 minutes of blood collection on Sysmex $\mathrm{XN}-3000$ equipment (Sysmex, Kobe, Japan).

Lactate Dehydrogenase and Plasma Hemoglobin Measurement. Mice plasma samples were used to quantify the lactate dehydrogenase and hemoglobin through colorimetric assays using the Hemoglobin Colorimetric Assay (Cayman Chemical, Ann Arbor, Michigan) and Bilirubin Assay Kit (Sigma-Aldrich, St. Louis, MO) according to the manufacturer's procedure. Assays were done in duplicate.

Functional Studies in Esophagus Smooth Muscle Rings and Concentration-Response Curves. The esophagus was extracted, dissected, and cut into rings (1.5-2 mm in length). Rings of esophagus smooth muscle were placed in a 5 -ml organ system filled with Krebs solution at $37^{\circ} \mathrm{C}$ continuously bubbled with a mixture of $95 \% \mathrm{O}_{2}$ and $5 \% \mathrm{CO}_{2}(\mathrm{pH}$ 7.4). Isometric force was analyzed using a Power Laboratory version 7.2 system (ADInstruments, Sydney, Australia). The esophagus was allowed to equilibrate for 60 minutes under a resting tension of $1 \mathrm{mN}$.

Cumulative concentration-response curves for the muscarinic agonist carbachol (CCh; $10 \mathrm{nM}$ to $100 \mu \mathrm{M})$ and $\mathrm{KCl}(1 \mathrm{mM}$ to $1 \mathrm{M})$ were acquired in esophagus rings from control, PHZ-treated C57BL/6, SCD, eNOS ${ }^{-1-}$, and PHZ-treated eNOS ${ }^{-1-}$ mice. Esophagus contractile responses to these compounds were acquired in the absence and presence of NO-independent sGC stimulator 3-(4-amino-5cyclopropylpyrimidin-2-yl)-1-(2-fluorobenzyl)-1H-pyrazolo[3,4-b]pyridine (BAY 41-2272; $1 \mu \mathrm{M}, 15$ minutes) or NO donor sodium nitroprusside (SNP; $300 \mu \mathrm{M}, 15$ minutes).

Electrical-Field Stimulation in Esophagus Smooth Muscle Rings. Electrical-field stimulation (EFS) was applied to the rings of esophagus smooth muscle placed between two platinum electrodes connected to a Grass S88 stimulator (Astro-Med, Warwick, RI). EFS was conducted at $80 \mathrm{~V}, 1-\mathrm{ms}$ pulse width, and trains of stimuli lasting 5 seconds at varying frequencies. Supra maximum voltage was applied to assess frequency-response relationships in all preparations using electrical stimulation. EFS-produced esophagus contractions were completely eliminated by either the muscarinic antagonist atropine $(10 \mu \mathrm{M})$ or the voltage-dependent sodium channel blocker tetrodotoxin (1 $\mu \mathrm{M})$, confirming that nerve-caused esophageal contractile responses are caused by acetylcholine discharge.

Data Analysis of Functional Assays. Potency (pEC50) was determined by nonlinear regression performed with GraphPad Prism (GraphPad Software, San Diego, CA) with the constraint that $F=0$. All concentration-response data were fitted to a logistic function expressed by the following equation: $\mathrm{E}=\mathrm{E}_{\max } /([1+(10 \mathrm{c} / 10 \mathrm{x}) \mathrm{n}]+\mathrm{F})$, where $\mathrm{E}$ is the maximum response induced by agonists; $c$ is the logarithm of the $\mathrm{EC}_{50}$, the concentration of drug that produces a half-maximal response; $\mathrm{x}$ is the logarithm of the concentration of the drug; the exponential term, $n$, is a curve-fitting parameter that defines the slope of the concentration-response line; and $\mathrm{F}$ is the response observed in the absence of added drug. Contractile response data were normalized to the wet weight of the respective esophagus rings. The $\mathrm{E}_{\max }$ is shown in $\mathrm{mN} / \mathrm{mg}$ wet weight.

Western Blot Analysis. Esophageal tissue was homogenized in lysis buffer and centrifuged at $12,000 \mathrm{~g}$ for 20 minutes at $4{ }^{\circ} \mathrm{C}$. Homogenates containing $50 \mu \mathrm{g}$ of total protein were run on $4 \%-20 \%$ Tris-HCl gels (Bio-Rad Laboratories, Hercules, CA) and transferred to a nitrocellulose membrane. Five-percent nonfat dry milk (Bio-Rad) in 
Tris-buffered saline/Tween was used for 1 hour at $24^{\circ} \mathrm{C}$ to block nonspecific binding sites. Membranes were incubated for 15-16 hours at $4^{\circ} \mathrm{C}$ with the following antibodies: monoclonal anti-3-nitrotyrosine (anti-3-NT; 1:1000, ab7048; Abcam, Cambridge, MA) and polyclonal anti-4-hydroxynonenal (anti-4-HNE; 1:1000, ab46545; Abcam). Densitometry was analyzed using the ImageJ software (National Institutes of Health, Bethesda, MD). Quantified densitometry results of $3-\mathrm{NT}$ and 4 -HNE were normalized to $\beta$-actin.

Drugs. BAY 41-2272 and CCh were acquired from Sigma-Aldrich. Analytical grade was required for all reagents. Either deionized water or dimethylsulfoxide was used as a solvent, and working solutions were diluted prior to use. The final concentration of dimethylsulfoxide was $0.1 \%$

Statistical Analysis. Statistical analysis was performed with GraphPad Prism (GraphPad Software). Data are expressed as the mean \pm S.E.M. of $N$ experiments. Student's unpaired $t$ test and oneway analysis of variance with Tukey post-test were used when comparing two or more than two groups, respectively. A $P$ value below 0.05 was considered statistically significant.

\section{Results}

Hematologic Parameters. Hematologic parameters (red blood cells, total hemoglobin, hematocrit, lactate dehydrogenase, and reticulocyte) showed that PHZ and SCD mice had severe anemia compared with control mice (Fig. 1). Plasma hemoglobin was greater in PHZ and SCD compared with the control group (Fig. 1C). Moreover, plasma hemoglobin was higher in PHZ compared with SCD mice, indicating that intravascular hemolysis, as expected, is more exaggerated in PHZ mice than in SCD (Fig. 1C).

Exaggerated Intravascular Hemolysis Leads to Esophageal Hypercontractility in Mice. In control, SCD, and PHZ mice, the muscarinic agonist $\mathrm{CCh}(10 \mathrm{nM}$ to $100 \mu \mathrm{M})$ produced concentration-dependent esophagus contractions (Fig. 2A). The values of $\mathrm{E}_{\max }$ were significantly greater in the $\mathrm{PHZ}$ mice esophagi $(0.75 \pm 0.03 \mathrm{mN} / \mathrm{mg})$ in comparison with the control group $(0.51 \pm 0.03 \mathrm{mN} / \mathrm{mg})($ Fig. $2 \mathrm{~A})$. We used a $\mathrm{KCl}$ concentration-response curve to assess esophagus contractions independently of receptor stimulation. $\mathrm{E}_{\max }$ values produced by $\mathrm{KCl}$ were also higher $(P<0.05)$ in $\mathrm{PHZ}$ esophagi $(0.45 \pm 0.01 \mathrm{mN} / \mathrm{mg})$ compared with control mice $(0.28 \pm$ $0.02 \mathrm{mN} / \mathrm{mg}$ ). We found no change in esophagus contractile responses produced by $\mathrm{CCh}$ and $\mathrm{KCl}$ in $\mathrm{SCD}$ mice (Fig. 2, $\mathrm{C}$ and $\mathrm{D})$. No significant difference in $\mathrm{pEC}_{50}$ for $\mathrm{CCh}$ was found between groups (Table 1).

NO Donor Did Not Modify the Increased Esophagus Contractions. Preincubation of esophagus with NO donor $\mathrm{SNP}(300 \mu \mathrm{M})$ did not change the increased esophagus smooth muscle contractions in $\mathrm{PHZ}$ mice induced by $\mathrm{CCh}$ (Fig. $3 \mathrm{~B}$ ) or $\mathrm{KCl}$ (Fig. 3D). No significant changes after SNP preincubation were detected in $\mathrm{CCh}$ - and $\mathrm{KCl}$-caused esophagus contractions of control mice (Fig. 3, A and C, respectively; Table 1).

sGC Stimulator Reversed the Increased Esophagus Contractions. Preincubation of esophagus with BAY 41-2272 $(1 \mu \mathrm{M})$ completely reversed the greater $\mathrm{E}_{\max }$ produced by $\mathrm{KCl}$ or $\mathrm{CCh}$ in PHZ mouse esophagus to control values (Fig. 4). No significant changes after BAY 41-2272 preincubation were detected in $\mathrm{CCh}$ - and $\mathrm{KCl}$-induced esophagus contractions of control mice (Fig. 4, A and $\mathrm{C}$, respectively). No significant change in $\mathrm{pEC}_{50}$ for $\mathrm{CCh}$ was found between groups (Table 1).

Contractile Responses Induced by Cholinergic Nerve Stimulation in Esophagus. EFS produced frequencydependent contraction esophageal rings $(8-32 \mathrm{~Hz})$ in both control and PHZ mice (Fig. 5A). EFS-caused contractions were significantly higher in esophagi from $\mathrm{PHZ}$ mice than in control mice at all frequencies tested (Fig. 5A). Preincubation of esophagus with BAY 41-2272 $(1 \mu \mathrm{M})$ reduced the increased neurogenic esophagus contractions in PHZ mice, but contractions remained unchanged with the preincubation with SNP (300 $\mu \mathrm{M}$; Fig. 5B). In control mice, preincubation of esophagus
A

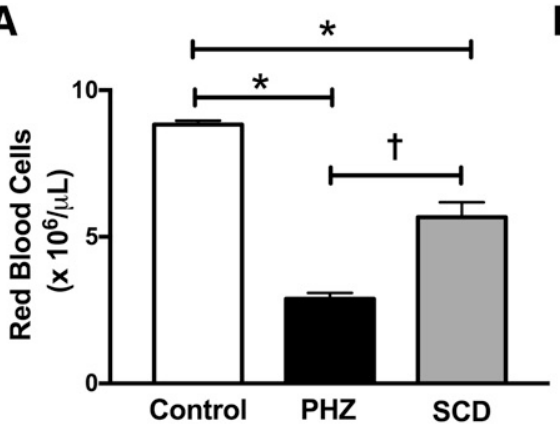

D

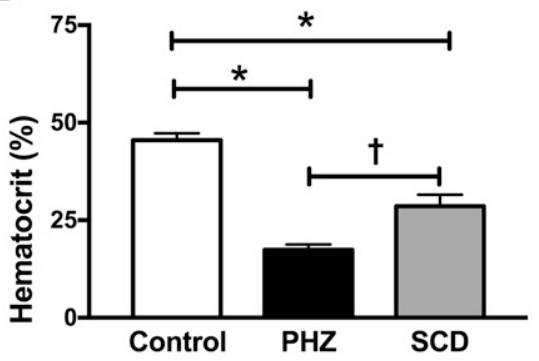

B

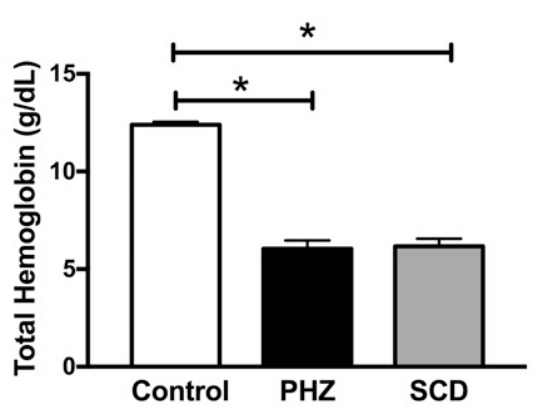

E

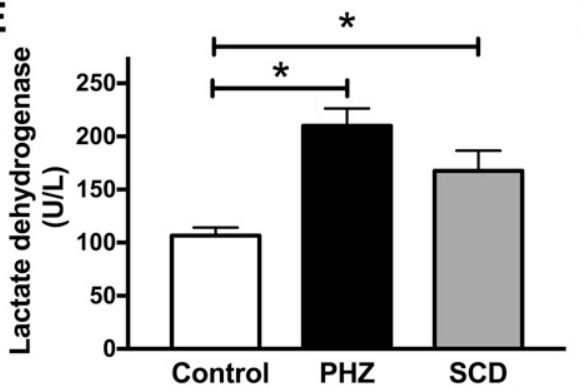

C

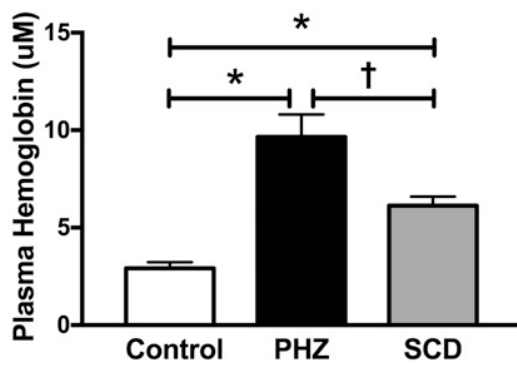

F

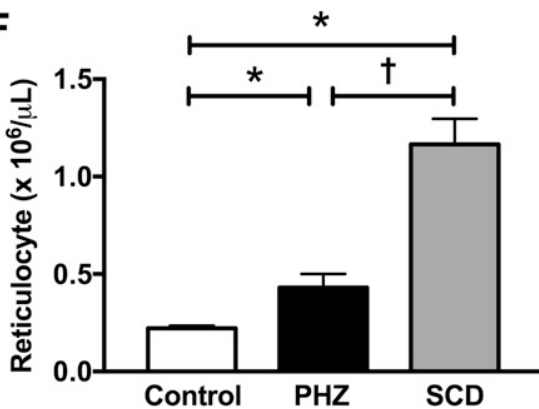

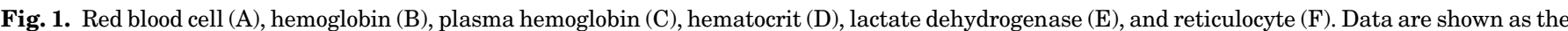
mean \pm S.E.M. of five to eight mice per group. ${ }^{*} P<0.05$ vs. control group; $\dagger P<0.05$ vs. PHZ group. 
A

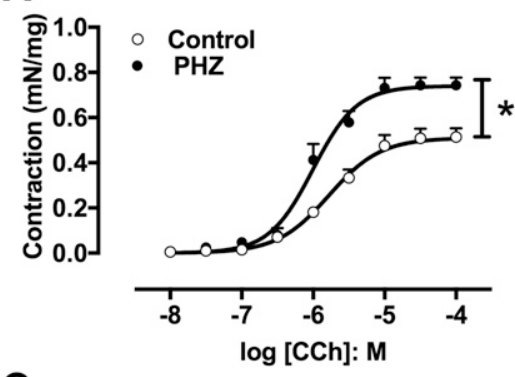

C

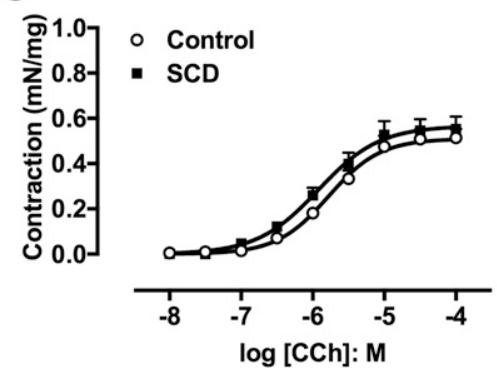

B

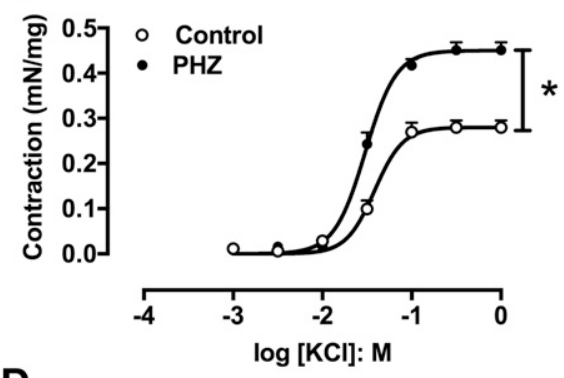

D

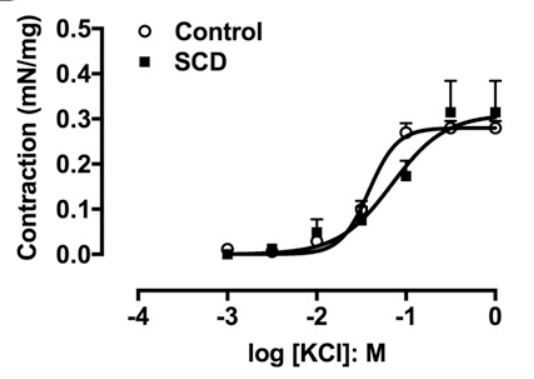

Fig. 2. Concentration-response curves for $\mathrm{CCh}(10 \mathrm{nM}$ to100 $\mu \mathrm{M})(\mathrm{A}$ and $\mathrm{C}$ ) or $\mathrm{KCl}(1 \mathrm{mM}$ to $1 \mathrm{M})(\mathrm{B}$ and $\mathrm{D})$ in esophageal rings from control, PHZ, and SCD mice. Data are shown as the mean \pm S.E.M. of five mice per group. ${ }^{*} P<0.05$ vs. control group. with SNP $(300 \mu \mathrm{M})$ or BAY 41-2272 $(1 \mu \mathrm{M})$ did not change the neurogenic contractions evoked by EFS (Fig. 5C).

Esophagus Smooth Muscles from PHZ Mice Display Increased Oxidative Stress. The protein expression for the 3-NT was about 2-fold higher in PHZ esophagi compared with control mice $(P<0.05$; Fig. 6A). Although we noticed a trend toward an increase in protein expressions for 4 -HNE in the PHZ group $(P=0.06)$, this did not reach statistical significance (Fig. 6B).

Intravascular Hemolysis Did Not Amplify the Esophageal Hypercontractility in eNOS $^{-1-}$ Mice. The muscarinic agonist $\mathrm{CCh}(10 \mathrm{nM}$ to $100 \mu \mathrm{M}$; Fig. 7A) and $\mathrm{KCl}(1 \mathrm{mM}$ to $1 \mathrm{M}$; Fig. 7C) caused concentration-dependent esophagus contractions in control, eNOS ${ }^{-/-}$, and PHZ-treated $\mathrm{eNOS}^{-/-}$ mice. The CCh (Fig. 7B) and $\mathrm{KCl}$ (Fig. 7D) $\mathrm{E}_{\max }$ values were significantly higher in the esophagi of $\mathrm{eNOS}^{-/-}$and eNOS $^{-1-}$-PHZ mice compared with control mice. Induction of intravascular hemolysis did not modify the higher $\mathrm{E}_{\max }$ elicited by $\mathrm{CCh}$ and $\mathrm{KCl}$ in esophagi from $\mathrm{eNOS}^{-/-}$mice. No significant changes in $\mathrm{pEC}_{50}$ for $\mathrm{CCh}$ was found between groups $(5.83 \pm 0.08,5.86 \pm 0.09$, and $5.89 \pm 0.06$ for control, $\mathrm{eNOS}^{-/-}$, and $\mathrm{eNOS}^{-/-}$-PHZ).

Iron-Chelating Drugs Treatment Did Not Change the Esophageal Hypercontractility in PHZ Mice. In separate groups, control and $\mathrm{PHZ}$ mice were treated with deferoxamine (intraperitoneally) or deferiprone (gavage). Treatment with deferoxamine did not modify the CCh- and KCl-induced esophagus contractile responses in control and $\mathrm{PHZ}$ mice (Fig. 8). Similarly, treatment with deferiprone did not modify the increased CCh $\mathrm{E}_{\max }$ in PHZ $(0.05 \pm 0.05 \mathrm{mN} / \mathrm{mg} ; n=4)$ and control mice $(0.47 \pm 0.02 \mathrm{mN} / \mathrm{mg} ; n=4)$.

\section{Discussion}

In PNH and SCD, elevated plasma hemoglobin levels consume micromolar concentrations of exogenously supplied NO (Reiter et al., 2002; Hill et al., 2010). The low NO bioavailability has been associated with pulmonary hypertension, platelet activation, thrombosis, and alterations of vasomotor tone in patients with PNH or SCD (Moyo et al., 2004; Villagra et al., 2007; Hill et al., 2010). Moreover, excess plasma hemoglobin has been associated with esophageal spasm in PNH patients (Moyo et al., 2004; Parker et al., 2005). Therefore, considering that intravascular hemolysis leads to NO deficiency and alterations of smooth muscle tone, we investigated the effects of intravascular hemolysis on esophagus smooth muscle contractile mechanisms in two murine models that display different levels of intravascular hemolysis, SCD and PHZ mice. In fact, PHZ-treated mice displayed a significant increase in plasma hemoglobin compared with SCD mice. In our study, we analyzed the in vitro receptor-dependent (muscarinic receptor agonist $\mathrm{CCh}$ ) and receptor-independent (responses to $\mathrm{KCl}$ ) contractile responses in esophagi from PHZ and SCD mice. The maximal contractile response to $\mathrm{CCh}$ and $\mathrm{KCl}$ was higher in the PHZ group, but no significant differences were observed in SCD mice. It is likely that reduction of basal NO by plasma hemoglobin may favor the hypercontractile state of the esophagus smooth muscle in PHZ mice. On the other hand, our findings indicate that an excess of cell-free hemoglobin is not abundant enough to promote esophagus injury in SCD.

\section{TABLE 1}

Potency $\left(\mathrm{pEC}_{50}\right)$ values obtained from concentration-response curves in esophageal rings from control, PHZ, SCD, $\mathrm{eNOS}^{-/-}$, and eNOS ${ }^{-1-}$-PHZ mice

Concentration-response curves for $\mathrm{CCh}(10 \mathrm{nM}$ to $100 \mu \mathrm{M})$ and $\mathrm{KCl}(1 \mathrm{mM}$ to $1 \mathrm{M})$ in the absence and in the presence of either SNP $(300 \mu \mathrm{M})$ or BAY 41-2272 (BAY; $1 \mu \mathrm{M})$. Data represent the mean \pm S.E.M. of five experiments.

\begin{tabular}{lccc}
\hline & \multicolumn{3}{c}{$\mathrm{pEC}_{50}$} \\
\cline { 2 - 4 } & Control & $\mathrm{PHZ}$ & $\mathrm{SCD}$ \\
\hline $\mathrm{CCh}$ & $5.78 \pm 0.05$ & $6.00 \pm 0.05$ & $5.92 \pm 0.09$ \\
$\mathrm{CCh} / \mathrm{SNP}$ & $5.81 \pm 0.08$ & $5.91 \pm 0.05$ & n.d. \\
$\mathrm{CCH} / \mathrm{BAY}$ & $5.74 \pm 0.05$ & $5.88 \pm 0.07$ & n.d. \\
$\mathrm{KCl}$ & $1.41 \pm 0.04$ & $1.52 \pm 0.02$ & $1.15 \pm 0.12$ \\
$\mathrm{KCl} / \mathrm{SNP}$ & $1.33 \pm 0.03$ & $1.41 \pm 0.05$ & n.d. \\
$\mathrm{KCl} / \mathrm{BAY}$ & $1.13 \pm 0.08$ & $1.43 \pm 0.11$ & n.d. \\
\hline
\end{tabular}

n.d., not determined. 
A

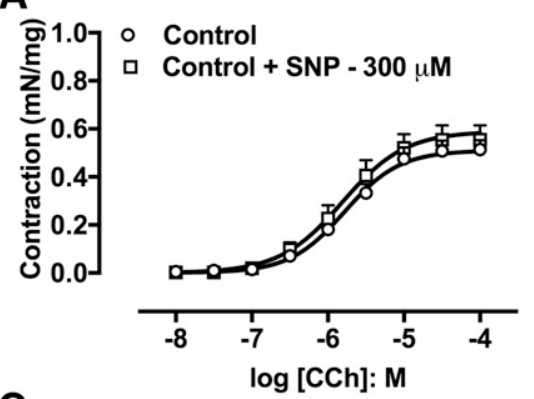

C

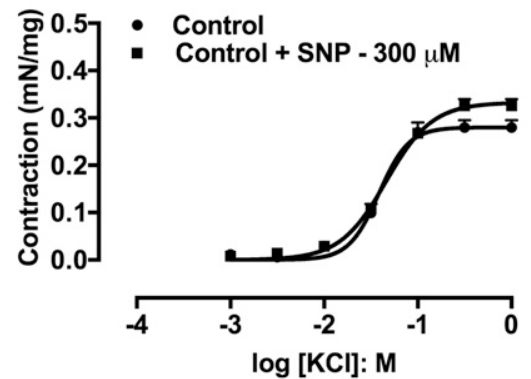

B

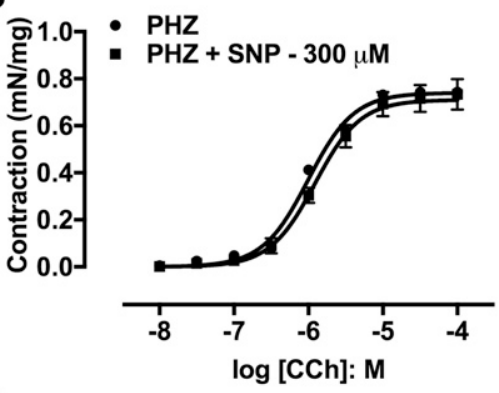

D

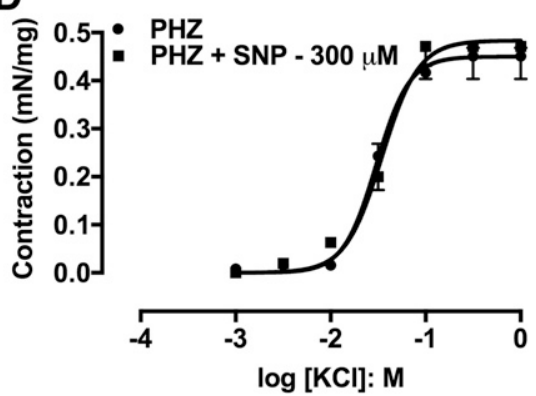

Fig. 3. Concentration-response curves for CCh (10 nM to $100 \mu \mathrm{M})(\mathrm{A}$ and $\mathrm{B})$ or $\mathrm{KCl}(1 \mathrm{mM}$ to $1 \mathrm{M})(\mathrm{C}$ and $\mathrm{D})$ in esophageal rings from control, $\mathrm{PHZ}$, and SCD mice in the absence or presence of SNP $(300 \mu \mathrm{M})$. Data are shown as the mean \pm S.E.M. of five mice per group.
Previous studies reported that intravenous administration of recombinant hemoglobin in healthy human volunteers caused increases in esophageal peristaltic amplitude, dysphagia, and abdominal pain (Murray et al., 1991; Viele et al., 1997; Carmichael et al., 2000).

To reinforce that dysregulation of the NO pathway leads to a hypercontractile state in the esophagus, we evaluated the esophagus contractile mechanisms in $\mathrm{eNOS}^{-/-}$mice, a model that displays low NO bioavailability. In fact, $\mathrm{eNOS}^{-1-}$ mice displayed a hypercontractile state in the esophagus compared with control mice. In $\mathrm{eNOS}^{-/-}$mice, induction of intravascular hemolysis by PHZ did not modify the esophagus contractile response. Our findings strongly indicate that intravascular hemolysis has a significant function in the development of esophageal dysfunction by reducing $\mathrm{NO}$ bioavailability. To our knowledge, our study is the first to show that $\mathrm{eNOS}^{-/-}$mice display increased esophagus contractile mechanisms.

The NO-cGMP signaling pathway is the main mediator of smooth muscle relaxation of the esophagus (Goyal and Chaudhury, 2008). Several NO donor compounds can supply exogenous NO to tissues and cells. SNP is an inorganic compound that provides NO to biologic systems by enzymatic and nonenzymatic mechanisms (Kowaluk et al., 1992; Bonaventura et al., 2008). In our study, we tested the effects of NO supplementation by SNP with the aim of reversing the esophageal hypercontractility from $\mathrm{PHZ}$ mice. In vitro incubation with SNP did not modify increased CCh- and $\mathrm{KCl}$-induced contractions in esophagi from $\mathrm{PHZ}$ mice. It is likely that hemoglobin in PHZ mouse esophagi acts to eliminate NO before it binds sGC. A previous study reported
A

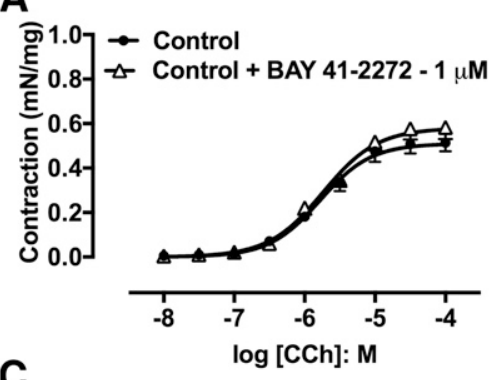

C

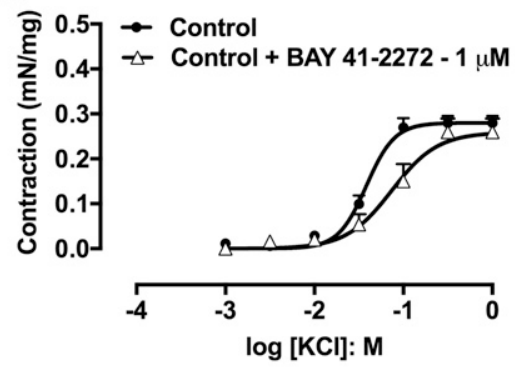

B

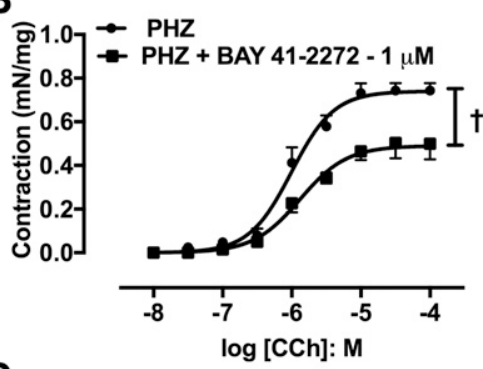

D

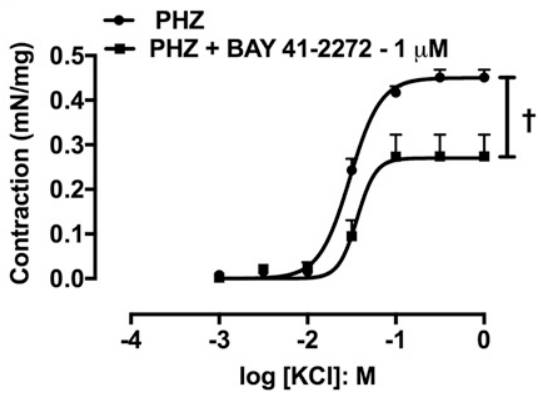

Fig. 4. Concentration-response curves for $\mathrm{CCh}(10 \mathrm{nM}$ to $100 \mu \mathrm{M})(\mathrm{A}$ and $\mathrm{B})$ or $\mathrm{KCl}(1 \mathrm{mM}$ to $1 \mathrm{M})(\mathrm{C}$ and $\mathrm{D})$ in esophageal rings from control, PHZ, and SCD mice in the absence or presence of BAY 41-2272 $(1 \mu \mathrm{M})$. Data are shown as the mean \pm S.E.M. of five mice per group. $\dagger P<0.05$ vs. PHZ group. 
A

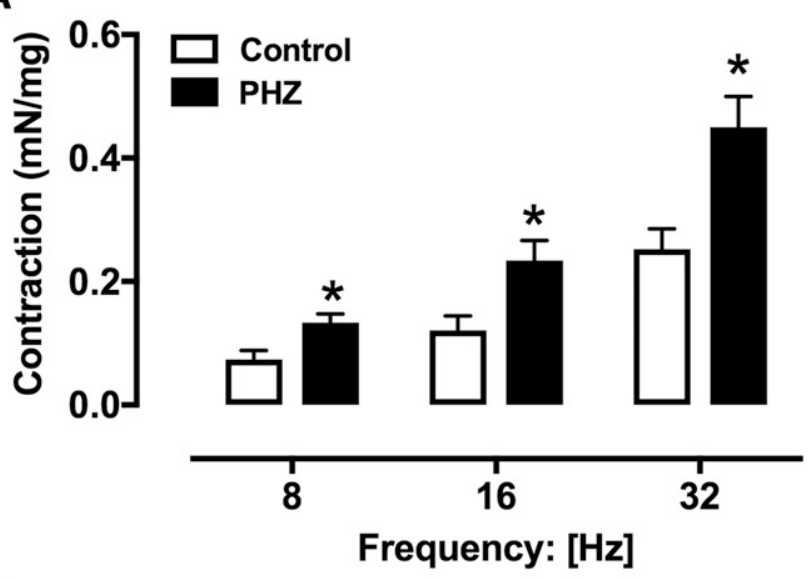

B

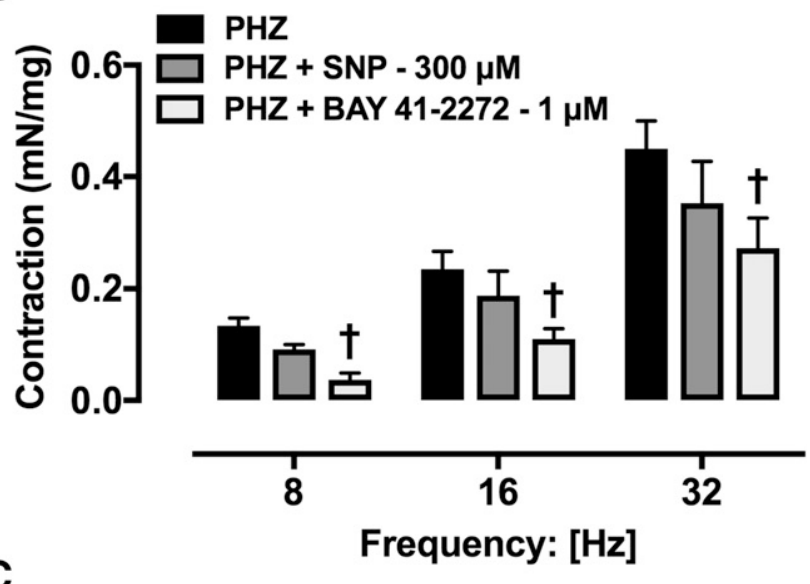

C

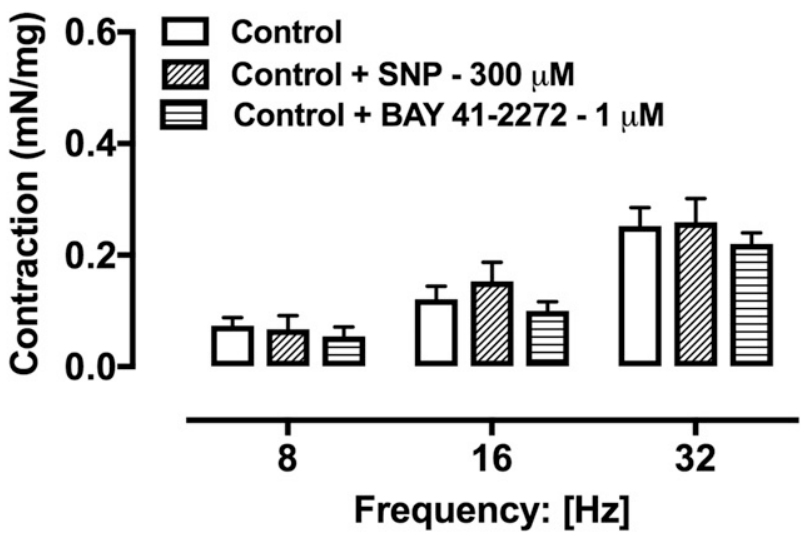

Fig. 5. Contractile responses to EFS (8-32 Hz) in esophageal rings from control (A and C) and PHZ mice (A and B) in the absence or presence of SNP $(300 \mu \mathrm{M})$ or BAY $41-2272(1 \mu \mathrm{M})$. Data are shown as the mean \pm S.E.M. of five mice per group. ${ }^{*} P<0.05$ vs. control group; $\uparrow P<0.05$ vs. PHZ group.

that extravascular translocation of plasma hemoglobin into interstitial spaces impairs the vasodilation induced by $\mathrm{NO}$ donor in pig and rat coronary arteries (Schaer et al., 2013). Recently, sGC stimulators, such as BAY 41-2272, emerged as potentially better therapeutic drugs because they can stimulate sGC mostly via NO-independent mechanisms (Stasch and Evgenov, 2013). In circumstances where excess concentration of plasma hemoglobin is enough to reduce NO bioavailability, sGC stimulators are beneficial to normalize cGMP-dependent vasodilation (Raat et al., 2013). In our study, in vitro incubation with BAY 41-2272 completely restored the responses to $\mathrm{CCh}$ and $\mathrm{KCl}$ in esophagi from $\mathrm{PHZ}$ mice, indicating that cGMP accumulation into esophagus smooth muscle acts to neutralize the NO deficiency. The selective phosphodiesterase 5 inhibitor sildenafil enhances intracellular cGMP levels and elevates NO-dependent smooth muscle relaxations (Francis et al., 2010). Consistent with our result, previous clinical studies showed that sildenafil decreases esophageal spasm and peristaltic amplitude in patients with esophageal motor alterations (Bortolotti et al., 2002; Eherer et al., 2002; Fox et al., 2007).

Neurotransmission is negatively modulated by NO released from nitrergic nerves (Bult et al., 1990). In fact, in vitro incubation of the esophagus body with L-NG-Nitroarginine; NG-nitro-L-Arginine (nonspecific nitric oxide synthase inhibitor) increases the EFS-induced esophageal contractile responses (Lecea et al., 2011). Previous studies showed that neuronal NO synthase gene-deficient mice display uncoordinated and higher esophagus contractions compared with wild mice (Müller et al., 2014). In this study, neurogenic contractions were greater in esophagi from $\mathrm{PHZ}$ compared with control mice, suggesting increased nerve-evoked acetylcholine release in the esophagus. This supports that the lack of neuronal nitric oxide synthase-derived NO contributions to esophageal hypercontractility in PHZ mice. Again, in vitro incubation with BAY 41-2272 (1 $\mu \mathrm{M})$ completely reversed the increased esophagus contractile responses to EFS in PHZ mice, but responses remained unchanged with preincubation with SNP. It is possible that the restoration of contractions by BAY 41-2272 in PHZ mice results in a high cGMP accumulation in the esophageal smooth muscle.

Oxidative stress has a significant function in the pathophysiology of hemolytic anemia, contributing to organ injury (Fibach and Dana, 2015). Elevated $\mathrm{O}_{2}^{-}$production reacts promptly with NO, reducing NO bioavailability and generating peroxynitrite, which is a potent oxidant and cytotoxic agent (Pacher et al., 2007). Peroxynitrite is a reactive nitrogen species that can cause the nitration of tyrosine residues, generating 3-NT (Pacher et al., 2007). The 3-NT protein is considered a consistent biomarker for evaluating the reactive nitrogen species formation (Halliwell, 1997). 4-HNE, a relatively stable end product of lipid peroxidation, is considered a biomarker of oxidative stress (Cohen et al., 2013). In our study, protein expression of 3-NT was increased in $\mathrm{PHZ}$ mice compared with the control group. Although there was a trend toward increased protein expression of 4-HNE in PHZ mice, it did not achieve statistical significance. Collectively, our data suggest that excess $\mathrm{O}_{2}^{-}$reduces $\mathrm{NO}$ bioavailability in esophagi from $\mathrm{PHZ}$ mice. In this circumstance, it is plausible to suggest that the enhanced $\mathrm{O}_{2}^{-}$production in esophageal smooth muscle acts to inactivate NO derived from either neuronal nitric oxide synthase or endothelial nitric oxide synthase, as well as exogenous NO released from SNP. Consistent with this hypothesis, previous studies showed that oxidative stress reduces relaxations induced by SNP in mesenteric artery and erectile tissue (Jiménez-Altayó et al., 2006; Silva et al., 2013).

In hemolytic anemia, accumulation of excess iron can occur in certain organs due to increased hemoglobin catabolism (Shi et al., 2016). Considering that free iron participates in the generation of reactive oxygen species (Winterbourn, 1995), we evaluated the effects of treatment with two iron-chelating 
A
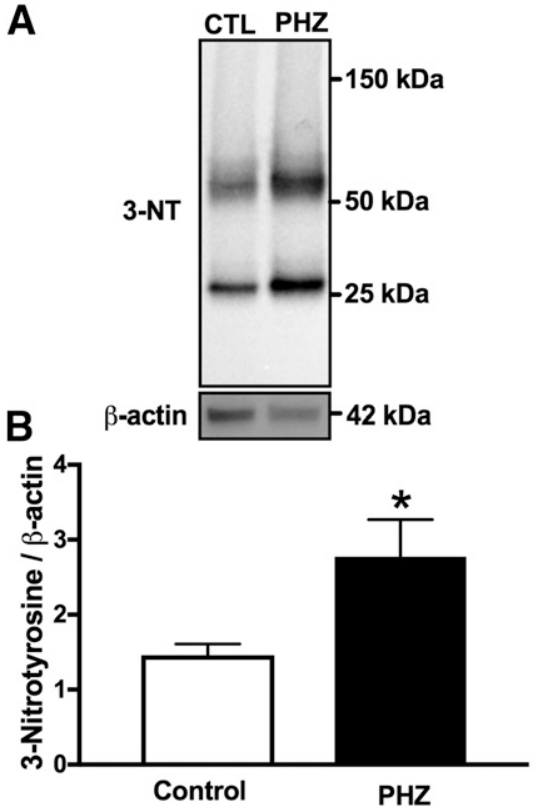
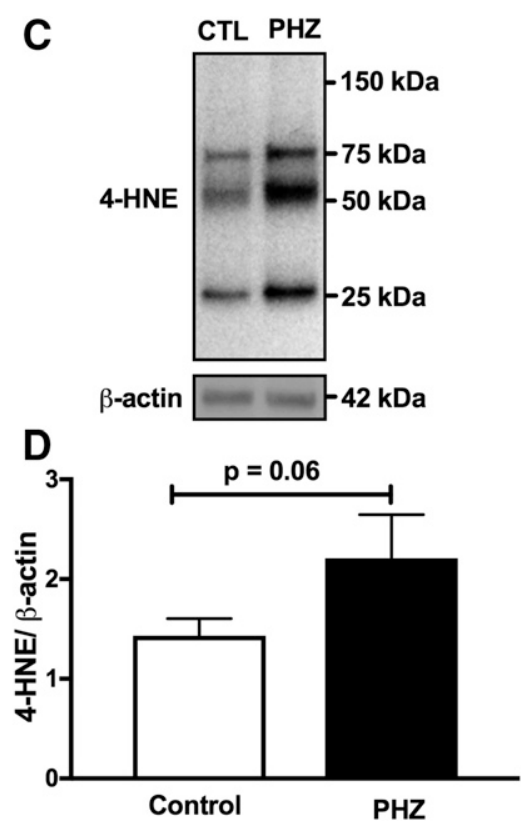

Fig. 6. Representative images of Western blotting (top panels) and protein values (bottom panels) for 3 -NT (A and B, respectively) and 4-HNE (C and D, respectively) in homogenates of esophagi from control (CTL) and PHZ mice. Data are shown as the mean \pm S.E.M. of five mice per group. ${ }^{*} P<0.05$ vs. control group. compounds (Pepe et al., 2011), deferiprone and deferoxamine, on esophageal hypercontractility in PHZ mice. PHZ mouse treatment with deferiprone and deferoxamine did not change hypercontractile state in the esophagus, indicating that excess of free iron is probably not associated with this disorder.

After hemolysis, free hemoglobin can translocate across the vascular wall and reach tissue interstitial spaces (Schaer et al., 2013). A limitation of our study is that we did not evaluate the localization of hemoglobin and nitric oxide synthases in the esophagus. However, previous evidence (Schaer et al., 2016) supports that free hemoglobin can scavenge nitric oxide in the vessels and causes vascular insufficiency in the esophageal vascular bed, impairing blood perfusion and resulting in ischemia. Ischemic conditions lead to oxidative stress, a known complication (Kalogeris et al., 2012). In fact, protein expression of 3-NT and 4-HNE increased in esophagi from $\mathrm{PHZ}$ mice. Therefore, esophageal vascular insufficiency may also play an important role in the development of an esophageal hypercontractile state.

In summary, our results show that the hypercontractile state seen in esophagi from $\mathrm{PHZ}$ mice is associated with decreased NO bioavailability in esophagus smooth muscle due to exaggerated intravascular hemolysis and oxidative stress. Moreover, BAY 41-2272 reversed the esophageal hypercontractility from $\mathrm{PHZ}$ mice, indicating that sGC stimulators may be an interesting approach to treat esophageal dysfunction in conditions of oxidative stress and elevated plasma hemoglobin levels. SCD mice do not present with obvious esophageal
A

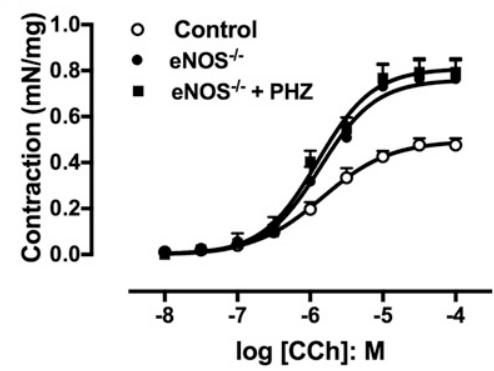

C

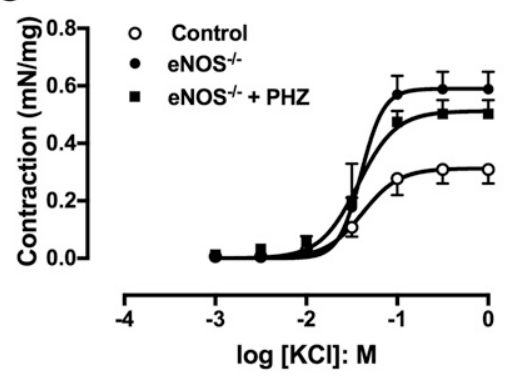

B

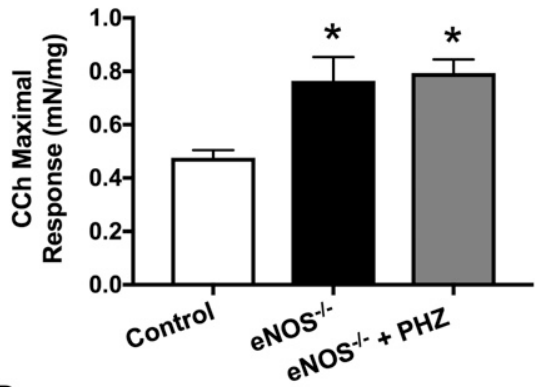

D

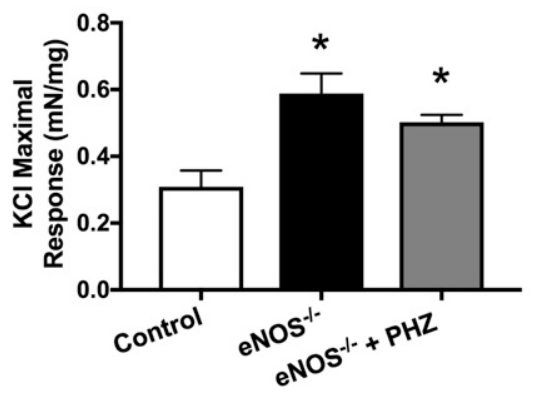

Fig. 7. Concentration-response curves for $\mathrm{CCh}(10 \mathrm{nM}$ to $100 \mu \mathrm{M})(\mathrm{A})$ or $\mathrm{KCl}(1 \mathrm{mM}$ to $1 \mathrm{M})(\mathrm{C})$ in esophageal rings from control, eNOS ${ }^{-1-}$, and $\mathrm{eNOS}^{-1-}-\mathrm{PHZ}$ mice. The maximal response values are shown in panels $\mathrm{B}$ and D. Data are shown as the mean \pm S.E.M. of five mice per group. $* P<0.05$ vs. control group. 
A

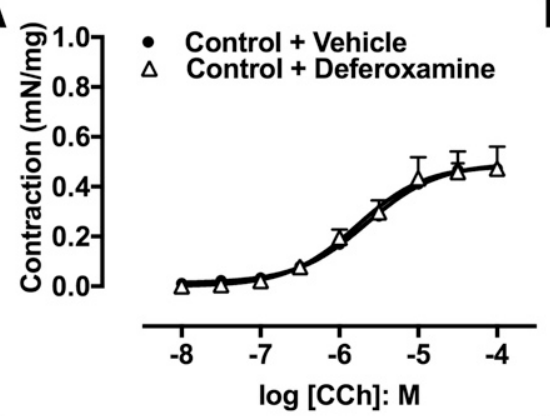

C

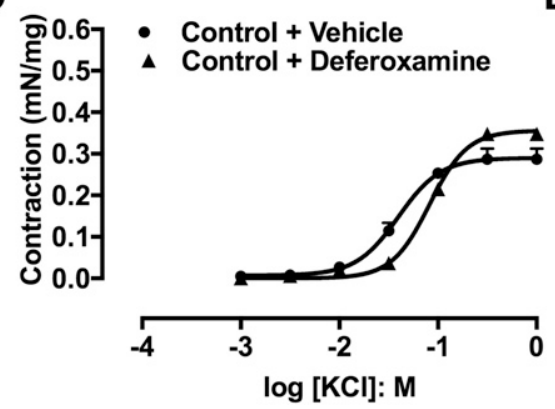

B

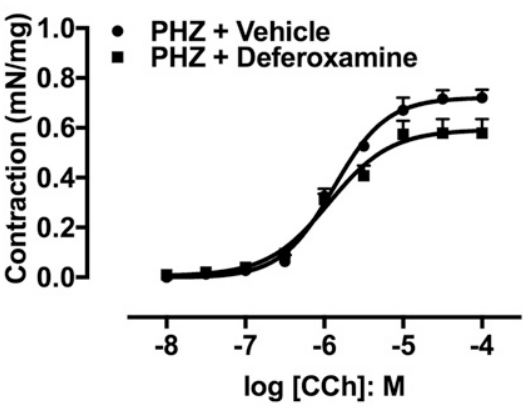

D

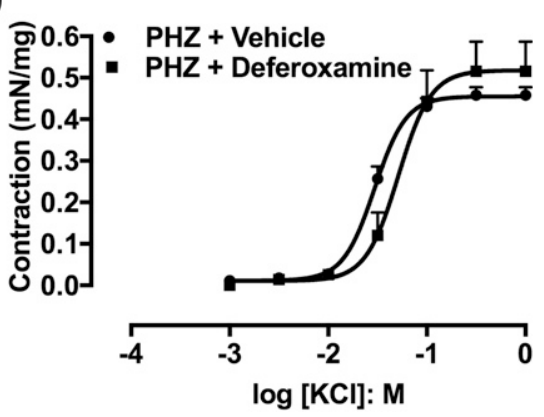

Fig. 8. Concentration-response curves for $\mathrm{CCh}(10 \mathrm{nM}$ to $100 \mu \mathrm{M})(\mathrm{A}$ and $\mathrm{B})$ or $\mathrm{KCl}(1 \mathrm{mM}$ to $1 \mathrm{M})(\mathrm{C}$ and $\mathrm{D})$ in esophageal rings from control and PHZ mice treated or not treated with deferoxamine. Data are shown as the mean \pm S.E.M. of five experiments per group. $* P<0.05$ vs. control group. disorder, indicating that the amount of excessive free hemoglobin is insufficient to cause esophageal damage in SCD. To the best of our knowledge, this study provides the first experimental evidence to support the hypothesis that esophageal symptoms in PNH patients are secondary to intravascular hemolysis affecting the NO-cGMP pathway.

\section{Acknowledgments}

We are thankful for the access to equipment and assistance provided by Dr. Edson Antunes' laboratory (Department of Pharmacology, University of Campinas).

\section{Authorship Contributions}

Participated in research design: Henrique Silva, Yotsumoto Fertrin, Ferreira Costa.

Conducted experiments: Henrique Silva, Fernanda Franco-Penteado, Alexandre, Calmasini.

Contributed new reagents or analytic tools: Ferreira Costa.

Performed data analysis: Henrique Silva, Ferreira Costa.

Wrote or contributed to the writing of the manuscript: Henrique Silva, Yotsumoto Fertrin, Ferreira Costa.

\section{References}

Bonaventura D, Lunardi CN, Rodrigues GJ, Neto MA, and Bendhack LM (2008) A novel mechanism of vascular relaxation induced by sodium nitroprusside in the isolated rat aorta. Nitric Oxide 18:287-295.

Bortolotti M, Pandolfo N, Giovannini M, Mari C, and Miglioli M (2002) Effect of Sildenafil on hypertensive lower oesophageal sphincter. Eur J Clin Invest 32: $682-685$.

Braverman AS, Miller LS, Vegesna AK, Tiwana MI, Tallarida RJ, and Ruggieri MR, $\mathrm{Sr}$ (2009) Quantitation of the contractile response mediated by two receptors: M2 and M3 muscarinic receptor-mediated contractions of human gastroesophageal smooth muscle. J Pharmacol Exp Ther 329:218-224.

Bult H, Boeckxstaens GE, Pelckmans PA, Jordaens FH, Van Maercke YM, and Herman AG (1990) Nitric oxide as an inhibitory non-adrenergic noncholinergic neurotransmitter. Nature 345:346-347.

Bunn HF, Nathan DG, Dover GJ, Hebbel RP, Platt OS, Rosse WF, and Ware RE (2010) Pulmonary hypertension and nitric oxide depletion in sickle cell disease. Blood 116:687-692

Carmichael FJL, Ali ACY, Campbell JA, Langlois SF, Biro GP, Willan AR, Pierce CH, and Greenburg AG (2000) A phase I study of oxidized raffinose cross-linked human hemoglobin. Crit Care Med 28:2283-2292.

Cohen G, Riahi Y, Sunda V, Deplano S, Chatgilialoglu C, Ferreri C, Kaiser N, and Sasson S (2013) Signaling properties of 4-hydroxyalkenals formed by lipid peroxidation in diabetes. Free Radic Biol Med 65:978-987.

Crosby WH (1955) The metabolism of hemoglobin and bile pigment in hemolytic disease. Am J Med 18:112-122.
Dutra FF, Alves LS, Rodrigues D, Fernandez PL, de Oliveira RB, Golenbock DT, Zamboni DS, and Bozza MT (2014) Hemolysis-induced lethality involves inflammasome activation by heme. Proc Natl Acad Sci USA 111:E4110-E4118.

Eherer AJ, Schwetz I, Hammer HF, Petnehazy T, Scheidl SJ, Weber K, and Krejs GJ (2002) Effect of sildenafil on oesophageal motor function in healthy subjects and patients with oesophageal motor disorders. Gut 50:758-764.

Fibach E and Dana M (2015) Oxidative stress in paroxysmal nocturnal hemoglobinuria and other conditions of complement-mediated hemolysis. Free Radic Biol Med 88 (Pt A):63-69.

Förstermann U and Sessa WC (2012) Nitric oxide synthases: regulation and function. Eur Heart J 33:829-837, 837a-837d.

Fox M, Sweis R, Wong T, and Anggiansah A (2007) Sildenafil relieves symptoms and normalizes motility in patients with oesophageal spasm: a report of two cases. Neurogastroenterol Motil 19:798-803.

Francis SH, Busch JL, Corbin JD, and Sibley D (2010) cGMP-dependent protein kinases and cGMP phosphodiesterases in nitric oxide and cGMP action. Pharmacol Rev 62:525-563.

Goyal RK and Chaudhury A (2008) Physiology of normal esophageal motility. J Clin Gastroenterol 42:610-619.

Groneberg D, Zizer E, Lies B, Seidler B, Saur D, Wagner M, and Friebe A (2015) Dominant role of interstitial cells of Cajal in nitrergic relaxation of murine lower oesophageal sphincter. J Physiol 593:403-414.

Halliwell B (1997) What nitrates tyrosine? Is nitrotyrosine specific as a biomarker of peroxynitrite formation in vivo? FEBS Lett 411:157-160.

Hill A, DeZern AE, Kinoshita T, and Brodsky RA (2017) Paroxysmal nocturnal haemoglobinuria. Nat Rev Dis Primers 3:17028.

Hill A, Rother RP, Wang X, Morris SM, Jr, Quinn-Senger K, Kelly R, Richards SJ, Bessler M, Bell L, Hillmen P, et al. (2010) Effect of eculizumab on haemolysisassociated nitric oxide depletion, dyspnoea, and measures of pulmonary hypertension in patients with paroxysmal nocturnal haemoglobinuria. $\mathrm{Br} J$ Haematol 149:414-425.

Inamori M, Shimamura T, Nagase H, Abe Y, Umezawa T, Nakajima A, Saito T, Ueno $\mathrm{N}$, Tanaka K, Sekihara H, et al. (2006) mRNA expression of inducible nitric oxide synthase, endothelial nitric oxide synthase and vascular endothelial growth factor in esophageal mucosa biopsy specimens from patients with reflux esophagitis. Hepatogastroenterology 53:361-365.

Jiménez-Altayó F, Briones AM, Giraldo J, Planas AM, Salaices M, and Vila E (2006) Increased superoxide anion production by interleukin-1beta impairs nitric oxidemediated relaxation in resistance arteries. J Pharmacol Exp Ther 316:42-52.

Kalogeris T, Baines CP, Krenz M, and Korthuis RJ (2012) Cell biology of ischemia/ reperfusion injury. Int Rev Cell Mol Biol 298:229-317.

Kato GJ, Steinberg MH, and Gladwin MT (2017) Intravascular hemolysis and the pathophysiology of sickle cell disease. J Clin Invest 127:750-760.

Kowaluk EA, Seth P, and Fung HL (1992) Metabolic activation of sodium nitroprusside to nitric oxide in vascular smooth muscle. J Pharmacol Exp Ther 262:916-922.

Lecea B, Gallego D, Farré R, Opazo A, Aulí M, Jiménez M, and Clavé P (2011) Regional functional specialization and inhibitory nitrergic and nonnitrergic coneurotransmission in the human esophagus. Am J Physiol Gastrointest Liver Physiol 300:G782-G794.

Lim SK, Kim H, Lim SK, bin Ali A, Lim YK, Wang Y, Chong SM, Costantini F, and Baumman $\mathrm{H}$ (1998) Increased susceptibility in Hp knockout mice during acute hemolysis. Blood 92:1870-1877.

Mearin F, Mourelle M, Guarner F, Salas A, Riveros-Moreno V, Moncada S, and Malagelada JR (1993) Patients with achalasia lack nitric oxide synthase in the gastro-oesophageal junction. Eur J Clin Invest 23:724-728. 
Moyo VM, Mukhina GL, Garrett ES, and Brodsky RA (2004) Natural history of paroxysmal nocturnal haemoglobinuria using modern diagnostic assays. $\mathrm{Br} J$ Haematol 126:133-138.

Müller M, Colcuc S, Drescher DG, Eckardt AJ, von Pein H, Taube C, Schumacher J, Gockel HR, Schimanski CC, Lang H, et al. (2014) Murine genetic deficiency of neuronal nitric oxide synthase (nNOS(-/-)) and interstitial cells of Cajal (W/W(v)): implications for achalasia? J Gastroenterol Hepatol 29:1800-1807.

Murray J, Du C, Ledlow A, Bates JN, and Conklin JL (1991) Nitric oxide: mediator of nonadrenergic noncholinergic responses of opossum esophageal muscle. Am $J$ Physiol 261:G401-G406.

Oni SB, Osunkoya BO, and Luzzatto L (1970) Paroxysmal nocturnal hemoglobinuria: evidence for monoclonal origin of abnormal red cells. Blood 36:145-152.

Pacher P, Beckman JS, and Liaudet L (2007) Nitric oxide and peroxynitrite in health and disease. Physiol Rev 87:315-424.

Parker C, Omine M, Richards S, Nishimura J, Bessler M, Ware R, Hillmen P, Luzzatto L, Young N, Kinoshita T, et al.; International PNH Interest Group (2005) Diagnosis and management of paroxysmal nocturnal hemoglobinuria. Blood 106:3699-3709.

Pepe A, Meloni A, Capra M, Cianciulli P, Prossomariti L, Malaventura C, Putti MC Lippi A, Romeo MA, Bisconte MG, et al. (2011) Deferasirox, deferiprone and desferrioxamine treatment in thalassemia major patients: cardiac iron and function comparison determined by quantitative magnetic resonance imaging. Haematologica 96:41-47.

Raat NJH, Tabima DM, Specht PAC, Tejero J, Champion HC, Kim-Shapiro DB, Baust J, Mik EG, Hildesheim M, Stasch J-P, et al. (2013) Direct sGC activation bypasses NO scavenging reactions of intravascular free oxy-hemoglobin and limits vasoconstriction. Antioxid Redox Signal 19:2232-2243.

Reiter CD, Wang X, Tanus-Santos JE, Hogg N, Cannon RO, III, Schechter AN, and Gladwin MT (2002) Cell-free hemoglobin limits nitric oxide bioavailability in sickle-cell disease. Nat Med 8:1383-1389.

Schaer CA, Deuel JW, Schildknecht D, Mahmoudi L, Garcia-Rubio I, Owczarek C, Schauer S, Kissner R, Banerjee U, Palmer AF, et al. (2016) Haptoglobin preserves vascular nitric oxide signaling during hemolysis. Am J Respir Crit Care Med 193: $1111-1122$

Schaer DJ, Buehler PW, Alayash AI, Belcher JD, and Vercellotti GM (2013) Hemolysis and free hemoglobin revisited: exploring hemoglobin and hemin scavengers as a novel class of therapeutic proteins. Blood 121:1276-1284.
Shah V, Lyford G, Gores G, and Farrugia G (2004) Nitric oxide in gastrointestinal health and disease. Gastroenterology 126:903-913.

Shi PA, Choi E, Chintagari NR, Nguyen J, Guo X, Yazdanbakhsh K, Mohandas N, Alayash AI, Manci EA, Belcher JD, et al. (2016) Sustained treatment of sickle cell mice with haptoglobin increases HO- 1 and H-ferritin expression and decreases iron deposition in the kidney without improvement in kidney function. Br J Haematol 175:714-723.

Silva FH, Mónica FZ, Báu FR, Brugnerotto AF, Priviero FBM, Toque HA, and Antunes E (2013) Superoxide anion production by NADPH oxidase plays a major role in erectile dysfunction in middle-aged rats: prevention by antioxidant therapy. J Sex Med 10:960-971.

Stasch J-P and Evgenov OV (2013) Soluble guanylate cyclase stimulators in pulmonary hypertension. Handb Exp Pharmacol 218:279-313.

Viele MK, Weiskopf RB, and Fisher D (1997) Recombinant human hemoglobin does not affect renal function in humans: analysis of safety and pharmacokinetics. Anesthesiology 86:848-858.

Villagra J, Shiva S, Hunter LA, Machado RF, Gladwin MT, and Kato GJ (2007) Platelet activation in patients with sickle disease, hemolysis-associated pulmonary hypertension, and nitric oxide scavenging by cell-free hemoglobin. Blood 110: $2166-2172$

Winterbourn CC (1995) Toxicity of iron and hydrogen peroxide: the Fenton reaction. Toxicol Lett 82-83:969-974.

Yamato S, Spechler SJ, and Goyal RK (1992) Role of nitric oxide in esophageal peristalsis in the opossum. Gastroenterology 103:197-204.

Yazaki E and Sifrim D (2012) Anatomy and physiology of the esophageal body. Dis Esophagus 25:292-298.

Zhang L, Prak L, Rayon-Estrada V, Thiru P, Flygare J, Lim B, and Lodish HF (2013) ZFP36L2 is required for self-renewal of early burst-forming unit erythroid progenitors. Nature 499:92-96.

Address correspondence to: Dr. Fabio Henrique Silva, Hematology and Hemotherapy Center, University of Campinas-UNICAMP, Rua Carlos Chagas, 480, Cidade Universitária, 13083-970, Campinas-SP, Brazil. E-mail: fabiohsilva87@gmail.com 